
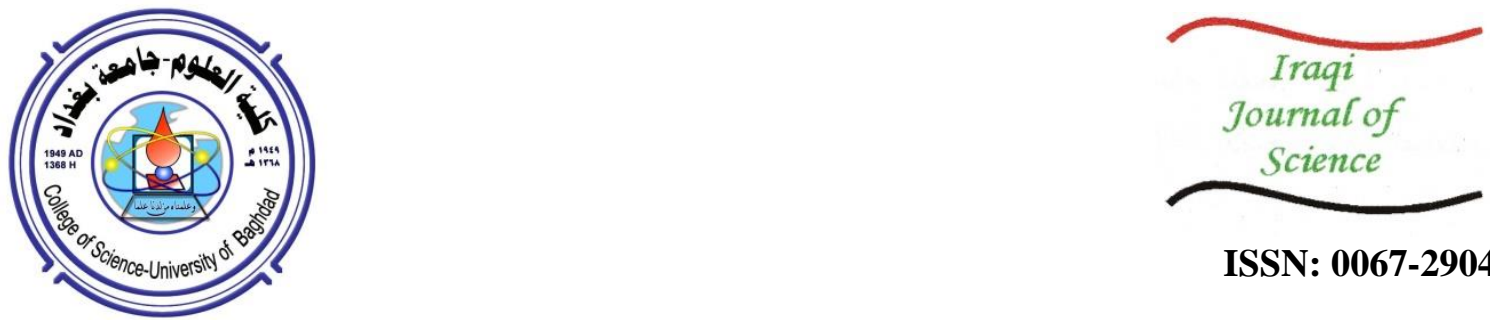

ISSN: 0067-2904

\title{
A Practical Method to Calculate and Model the Petrophysical Properties of Reservoir Rock Using Petrel Software: A case Study from Iraq
}

\author{
Sarah Taboor Wali*, Hussain Ali Baqer \\ Petroleum Department, College of Engineering, University of Baghdad, Baghdad, Iraq
}

Received: $21 / 2 / 2020$

Accepted: 2/5/2020

\begin{abstract}
Nasiriyah oilfield is located in the southern part of Iraq. It represents one of the promising oilfields. Mishrif Formation is considered as the main oil-bearing carbonate reservoir in Nasiriyah oilfield, containing heavy oil (API $25^{\circ}$ ). The study aimed to calculate and model the petrophysical properties and build a three dimensional geological model for Mishrif Formation, thus estimating the oil reserve accurately and detecting the optimum locations for hydrocarbon production.

Fourteen vertical oil wells were adopted for constructing the structural and petrophysical models. The available well logs data, including density, neutron, sonic, gamma ray, self-potential, caliper and resistivity logs were used to calculate the petrophysical properties. The interpretations and environmental corrections of these logs were performed by applying Techlog 2015 software. According to the petrophysical properties analysis, Mishrif Formation was divided into five units (Mishrif Top, MA, shale bed, MB1 and MB2). A three-dimensional geological model, which represents an entrance for the simulation process to predict reservoir behavior under different hydrocarbon recovery scenarios, was carried out by employing Petrel 2016 software. Models for reservoir characteristics (porosity, permeability, net to gross NTG and water saturation) were created using the algorithm of Sequential Gaussian Simulation (SGS), while the variogram analysis was utilized as an aid to distribute petrophysical properties among the wells.

The process showed that the main reservoir unit of Mishrif Formation is MB1 with a high average porosity of $20.88 \%$ and a low average water saturation of $16.9 \%$. MB2 unit has good reservoir properties characterized by a high average water saturation of $96.25 \%$, while MA was interpreted as a water-bearing unit. The impermeable shale bed unit is intercalated between MA and MB1 units with a thickness of 5-18 m, whereas Mishrif top was interpreted as a cap unit. The study outcomes demonstrated that the distribution accuracy of the petrophysical properties has a significant impact on the constructed geological model which provided a better understanding of the study area's geological construction. Thus, the estimated reserve $\mathrm{h}$ was calculated to be about 7945 MSTB. This can support future reservoir development plans and performance predictions.
\end{abstract}

Keywords: Petro physical Properties; Reservoir modelling; Nasiriya Oilfield.

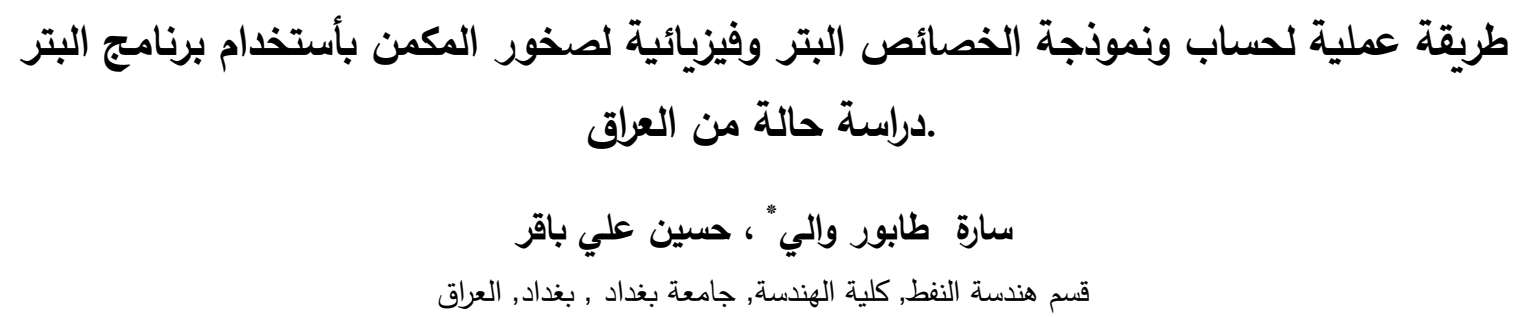

*Email: t.wsarah@yahoo.com 
يقع حقل الناصرية في الجزء الجنوبي من العراق وهو يمثل احد حقول النفط الواعدة. يعتبر تكوين المشرف

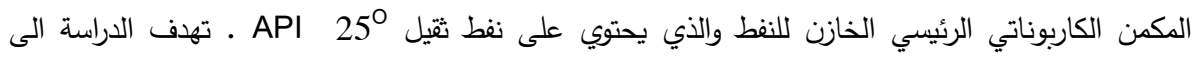
حساب ونمذجة الخصائص البتروفيزيائيه وبناء موديل جيولوجي ثلاثي الأبعاد لتكوين المشرف وبالتالي تقدير الأحتياطي النفطي بدقة وتحديد أفضل المواقع لأنتاج الهايدروكاربون. تم أعتماد 14 بئر نفطي عمودي لبناء النماذج الهيكلية والبتروفيزيائية. تم أستخدام بيانات الجس المتوفرة. والتي تضمنت density, neutron, sonic, gamma ray, self-potential, caliper and resistivity لحساب الخصائص البتروفيزيائية .تم تتفيذ التفسيرات والتصحيحات البيئية لهذه المجسات من خلال أستخدام برنامج 2015 .Techclog وفقا لتحليل الخصائص البتروفيزيائية تم تقسيم تكوين المشرف الى خمس وحدات( Mishrif Top, MA, Shale bed, MB1,MB2) • تم بناء موديل جيولوجي ثلاثي الأبعاد لتكوين المشرف في حقل الناصرية النفطي والذي يمثل مدخلا لعملية المحاكاة للتتبوء بتصرف المكمن في ظل

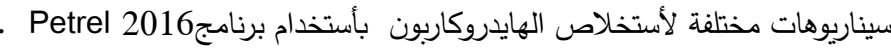
porosity, permeability, net to gross NTG, water ) موديلات الخصائص البتروفيزيائية (saturation تم انشاؤها بأستخدام خوارزمية Sequential Gaussian Simulation SGS والأستفادة من تحليل المتغيرات كعامل مساعد في نشر الخصائص البتروفيزيائية بين الآبار . بينت عملية النمذجة بأن الوحدة المكمنية الرئيسية لتكوين المشرف هي 20.88\% ومعدل تشبع مائي منخفض 16.9\%, الخصائص المكمنية للوحدة MB2 بيدة وتميزت بمعدل shale bed تم تفسيرها كوحدة خازنه للماء. الوحدة الغير نفاذة MA بينبع مائي عالي

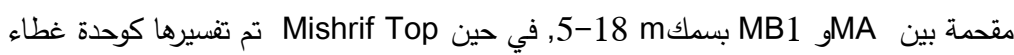
أظهرت نتائج الدراسة أن دقة توزيع الخصائص البتروفيزيائية لها تأثير كبير على الموديل الجيولوجي المبني والذي وفر فهما أفضل لمنطقة ألدراسة, وبالتالي الأحتياطي ألنفطي الذي تم حسابة ليكون حوالي 7945 MSTB هذا من شأنه أن يدعم خطط التطوير والتتبؤات المستقبلية للمكمن.

\section{1- Introduction}

Nasiriyah structure was discovered in 1975 and appeared as a longitudinal anticline with the northwest-southeast axial direction. The structure length is $30 \mathrm{Km}$ and its width is $10 \mathrm{Km}$, with an enclosure of 65-70 m [1]. Mishrif Formation represents the main oil-bearing reservoir in Nasiriyah oil field. It is one of the important carbonate reservoirs in the southern and central Iraqi oilfields which include Zubair, Amara, Majnoon, Halfaya, West Qurna, Buzergan and Rumaila [2].

The accurate estimation of petrophysical properties is the most challenging part of building a geological model. It has a great influence on fluid contact identification and, thus, reserve estimation. According to that, the reservoir must be divided into layers based on the dominated rock type to specify the trends and the average values of petrophysical parameters in reservoir rocks [3]. In petroleum industry, geological modelling is considered a discipline of engineering science that represent Earth's crust parts, especially hydrocarbon reservoirs [4]. The geological model is an essential concept in the simulation process to predict the reservoir performance under different hydrocarbon recovery scenarios and optimize the future reservoir development schemes. Modelling of quantitative geological processes is vital in reservoir assessment to understand the subsurface structures' spatial distribution, which represents the base of numerical simulation for hydrocarbon exploration and production. Subsurface modelling in three dimensions represents a mean to improve the interpretation of data by visualizing and confronting these data simultaneously with the created model [5].

The available well logs data, involving density, neutron, sonic, Gamma ray, resistivity, caliper and self-potential were evaluated and corrected using Techlog 2015 software for providing values concerning reservoir properties, including porosity and water saturation. The study aims to construct a three dimensional (3D) geological model by applying Petrel 2016 for Mishrif Formation in Nasiriyah oil field. The created geological model included reservoir structural design as well as a 3D modelling of stratigraphic and reservoir petrophysical properties. Geostatistics can be defined as a numerical collection technique that deals with the characterization of spatial attributes, applying foremost 
random models in a way similar to the manner where the analysis of time series identifies temporal data. Geostatistical modelling is preferred to be used in describing the spatial distribution and variation of reservoir properties, involving porosity and water saturation [6]. The classical geostatistical approach used to model the reservoir properties in this study was the Sequential Gaussian Simulation (SGS).

\section{2- Study Area}

Nasiriyah field is located in the NW-SE oriented Mesopotamian Zone extending across the alluvial plains of the Euphrates-Tigris valleys, about $38 \mathrm{~km}$ northwest of Thi Qar city (Figure-1). Mishrif Formation is the main reservoir in Nasiriyah oil field, characterized by fine to coarse bioclastic limestone deposited in a shallow depositional domain with an average thickness of $180 \mathrm{~m}$. Forty-five vertical oil wells were drilled in Nasiriyah oil field. This study relies on fourteen wells that all penetrate Mishrif Formation (Figure-2).

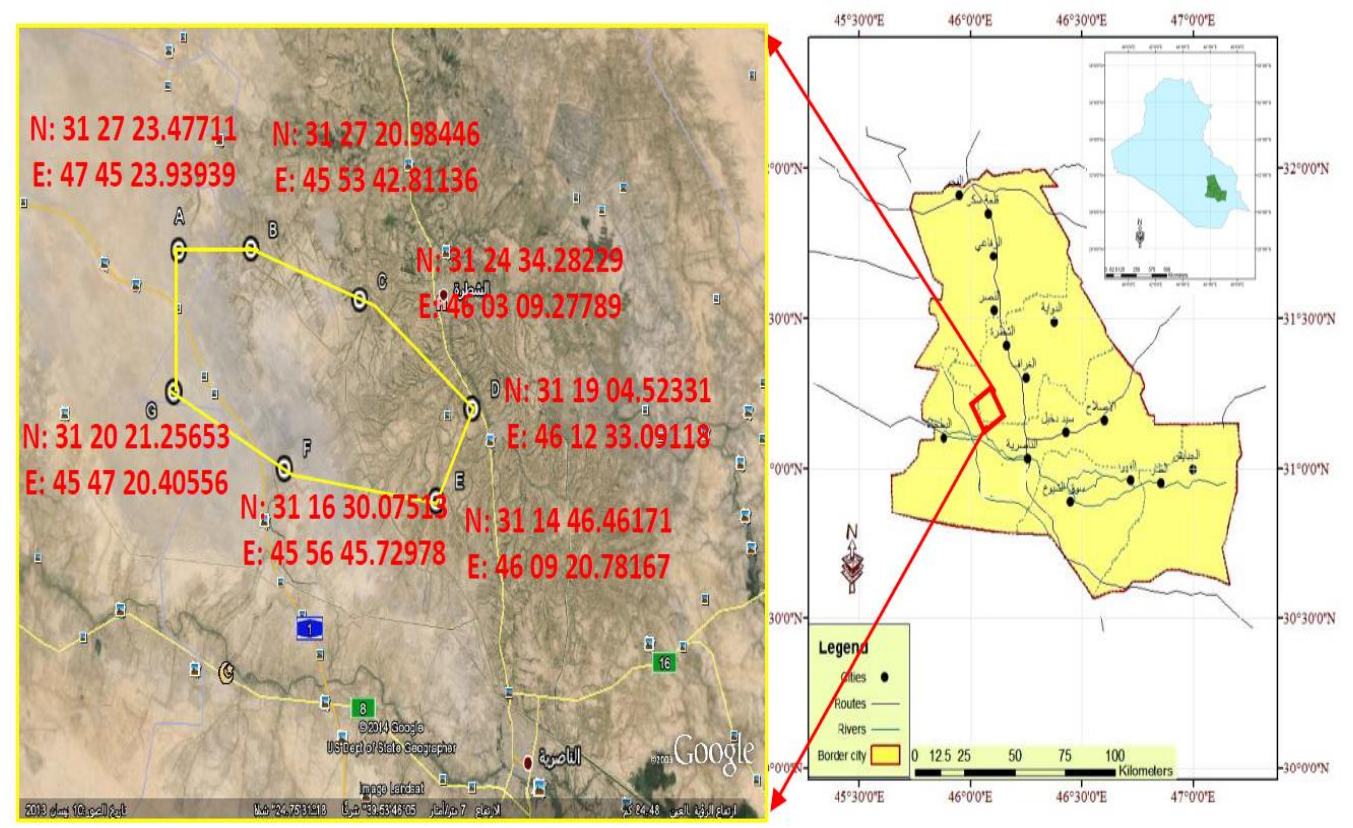

Figure 1-Geographic map and coordinates of the study area [2].

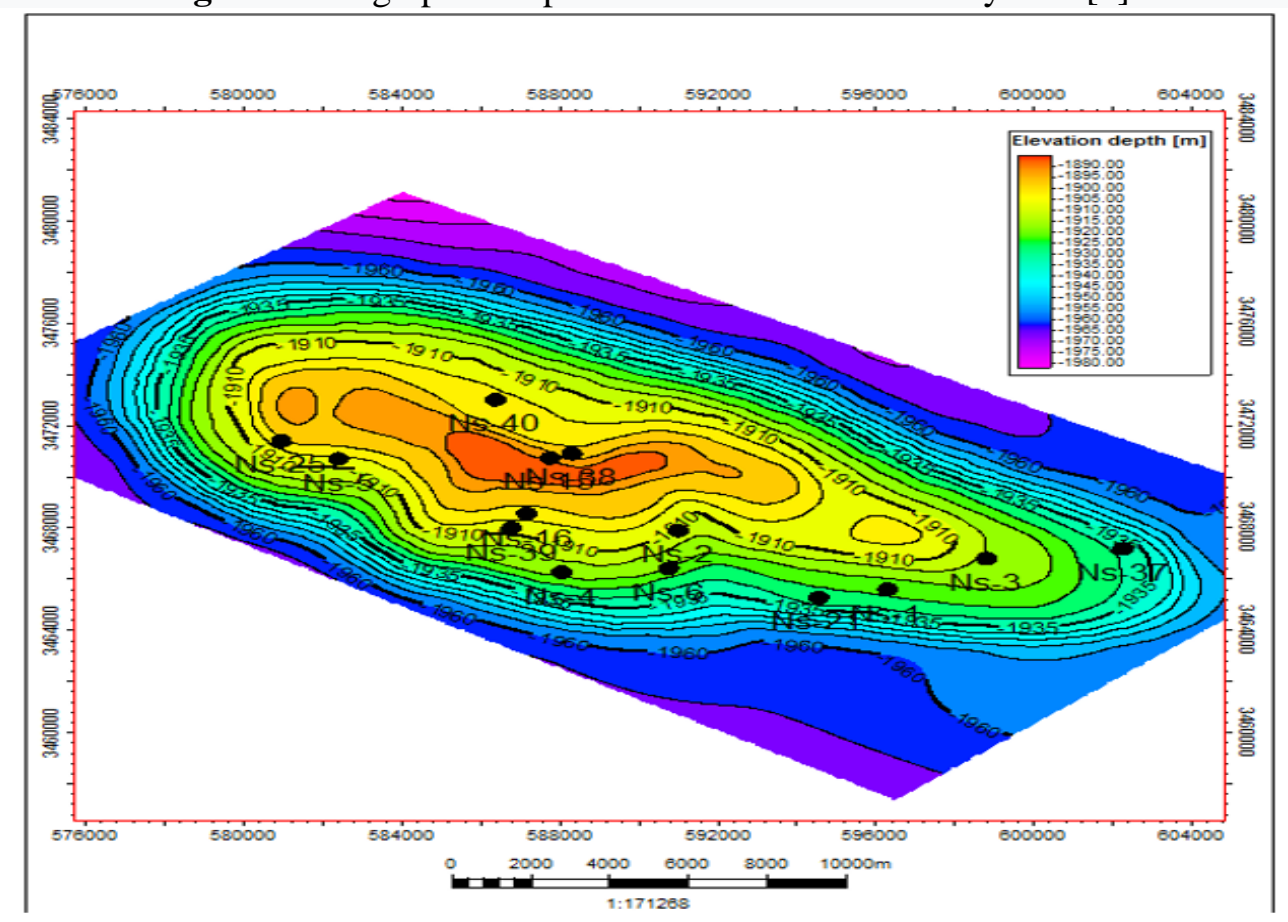

Figure 2-Wells' locations of Nasiriyah Oilfield. 


\section{3- Methodology}

This study was conducted starting with preparing the essential data, which are contour maps for Mishrif Formation units, wellheads that included the wells measured depth and coordinates in three dimensions, and well tops, along with well log data including density, neutron, sonic, gamma ray, selfpotential, caliper and resistivity. These data were interpreted and environmentally corrected by Techlog 2015 software and calibrated using special core analysis data. Petrel 2016 software developed by Schlumberger was employed to perform the study tasks, where the first phase was building the reservoir structural model representing the boundaries of the geological units. The second phase involved dividing Mishrif units into many layers for characterizing the vertical variance within each geological unit. The third phase included the scale-up of reservoir properties. The fourth phase included a property modelling procedure involving porosity and water saturation, where the variogram analysis was utilized as an aid to distribute the petrophysical properties among wells. The final step was oil reserve calculation.

\section{4- Structural Modelling}

Structural modelling for Mishrif Formation was built depending on wellheads, well tops and structural contour maps from 2-D seismic data for each unit (Mishrif top, MA, shale bed, MB1, MB2). The established structural model illustrated a full three-dimensional form of Mishrif Formation in Nasiriyah oil field (Figure-3) and provided essential geometric constraints for the geological model, which in turn showed that the Formation is a quite gentle NW-SE oriented anticline.

\section{5- 3D Grid construction}

The construction of a 3D grid is the essential step of building a 3D model. It represents a network of vertical and horizontal lines employed to characterize the 3D geological model. This step divided the model into boxes called grid cells where each grid cell had one value of porosity, water saturation, permeability and single rock type. These grid cells are referred to as cell properties [7] and this simplification is a true representation of the reality to be used in the calculations. The grid dimensions for Mishrif Formation in Nasiriyah oilfield were $200 \mathrm{~m}$ along the $\mathrm{x}$-axis and $200 \mathrm{~m}$ along the $\mathrm{y}$-axis.

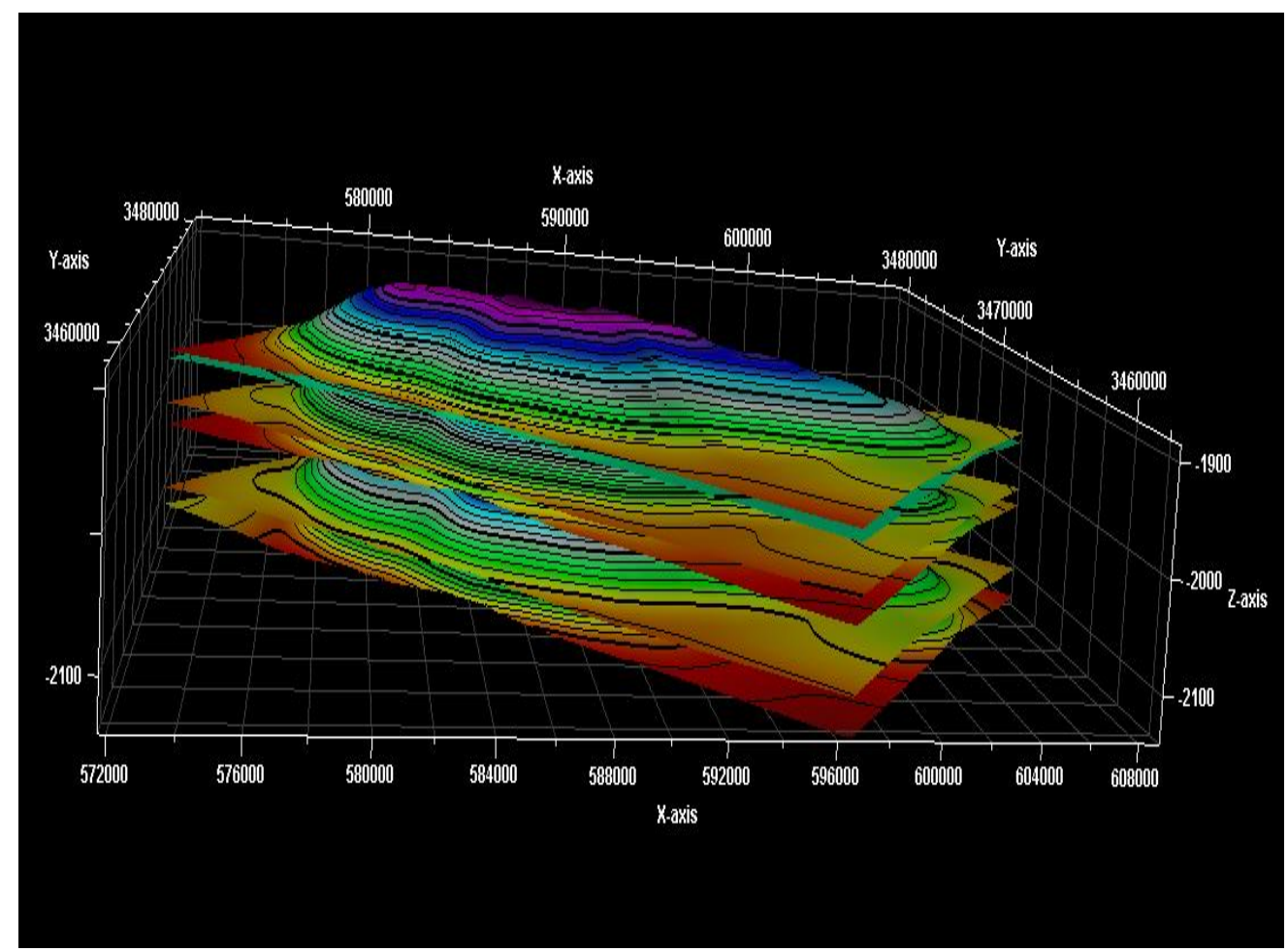

Figure 3-Structural Maps for Mishrif Formation Units.

\section{6- Layering}

Layering process reflects the geological deposition of a specific zone, where the modern geology requires that the layered volumes have to be accurately represented [7]. Layering procedure is 
considered as the final vertical framework subdivision (Figure-4). Mishrif reservoir units were divided into 34 layers according to their petrophysical properties, as detailed in the Table-1.

Table 1-Mishrif Units’ Layers

\begin{tabular}{|c|c|c|}
\hline Unit & Average Thickness (m) & Number of Layers. \\
\hline \hline Mishrif Top & 8.35 & 1 \\
\hline MA & 55.36 & 5 \\
\hline Shale bed & 11.44 & 17 \\
\hline MB1 & 66.90 & 10 \\
\hline MB2 & 31.8 & 17 \\
\hline
\end{tabular}

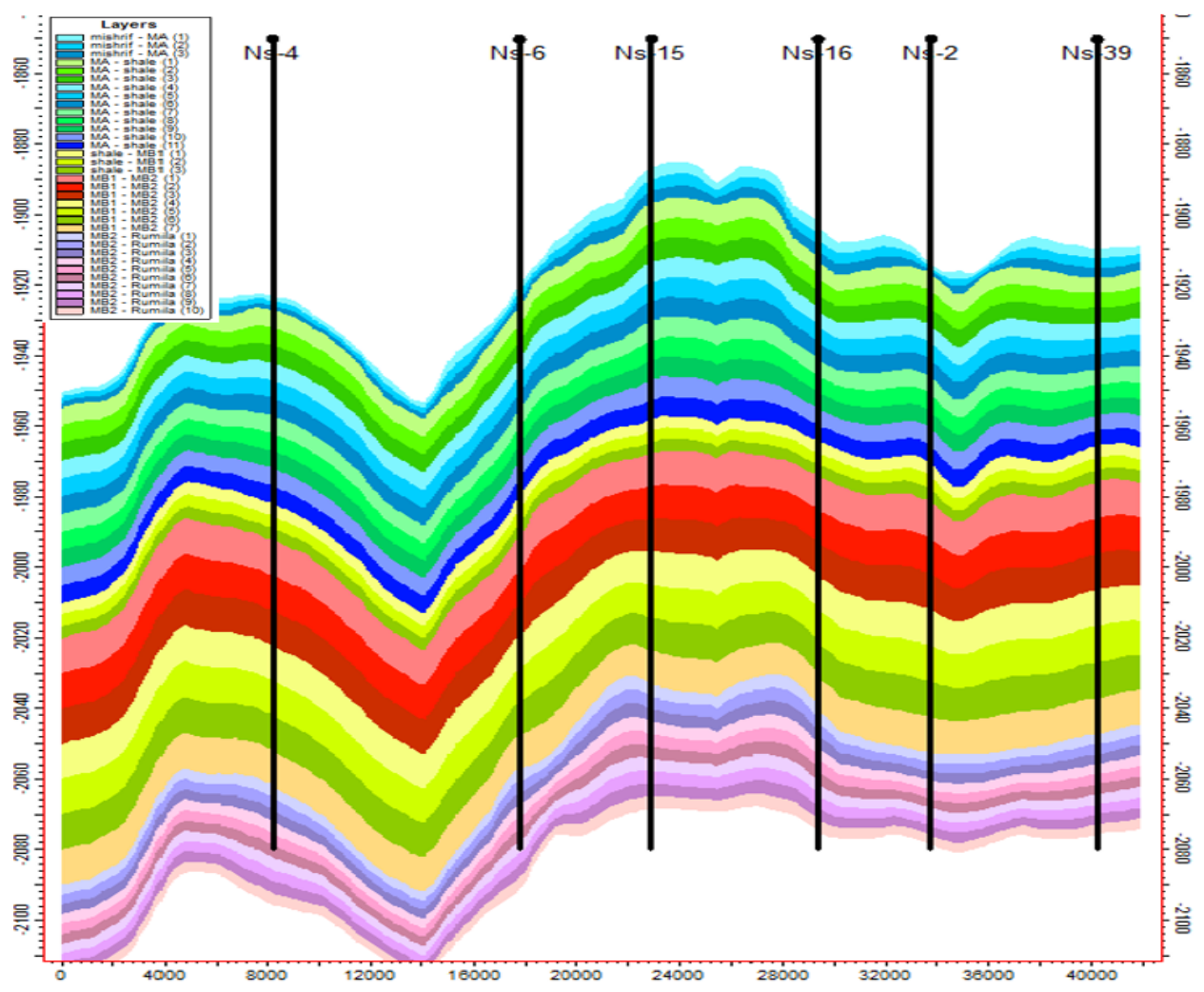

Figure 4-Cross-section in W-E direction for the Layers of Mishrif Formation in Nasiriyah oilfield.

\section{7- Well Log Upscaling}

Well log upscaling was performed to insert wells data into the model, for averaging cells' values within the 3-D grid, which are penetrated by the wells. In most cases, the resolution of logging interpretation data is higher than the 3D simulation grid. Consequently, up-scaling matches the wells data with the 3D grid data [8]. Statistical methods used for up-scaling include a geometric method, arithmetic average, and harmonic method [9]. The arithmetic average method was utilized to scale up porosity and water saturation, as shown in Figure-5. 


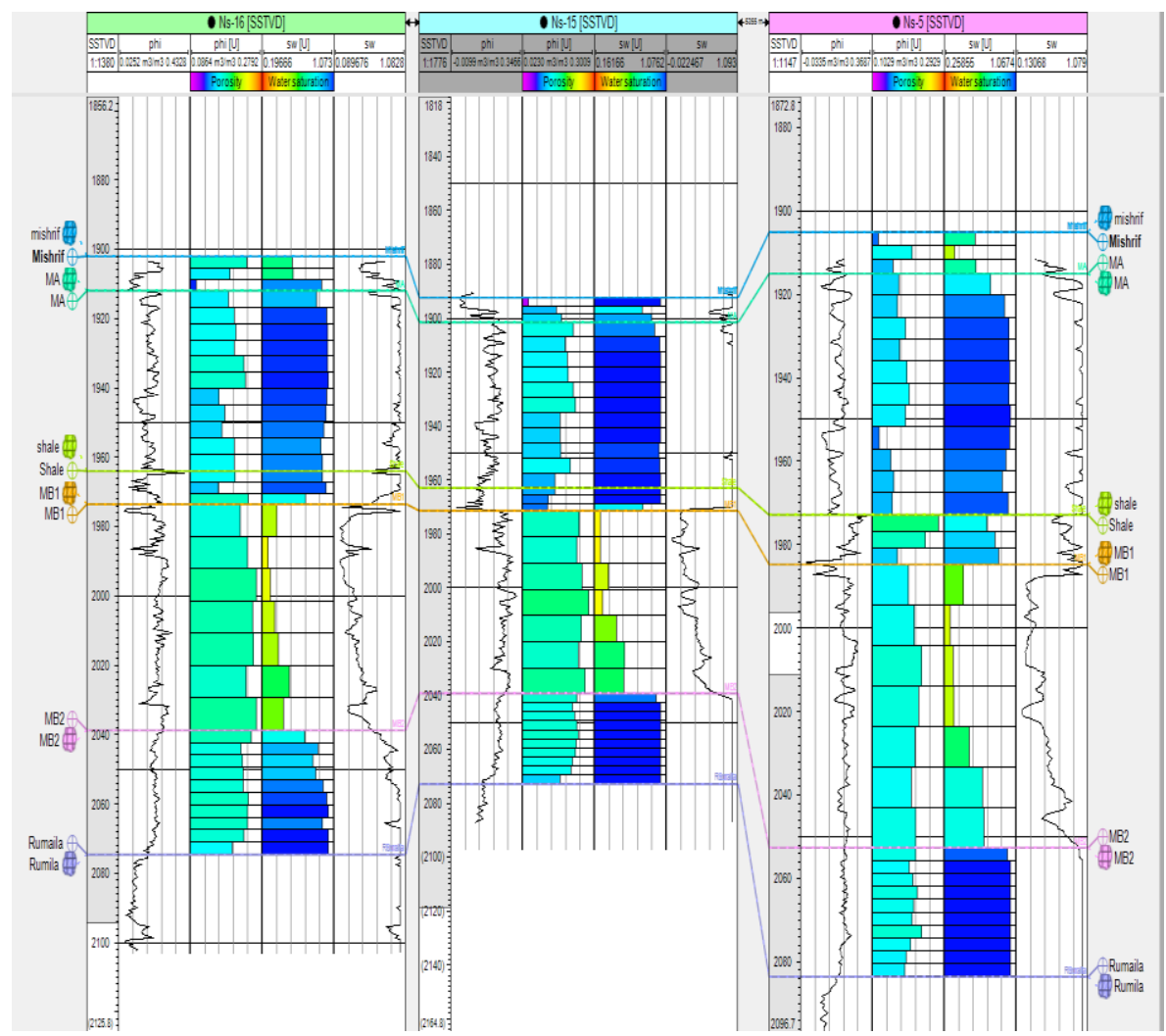

Figure 5-Scale-up of porosity and water saturation for wells Ns-5, Ns-15, Ns-16

\section{8- Oil Water Contact (OWC)}

Oil-water contact has a large influence on geomodelling and volumetric calculations [8]. The calculated initial oil-in-place range varies widely depending on the OWC location. In Nasiriyah field Mishrif Formation, each reservoir unit possibly has a different OWC. Free water level (FWL) could not be defined since wireline Formation pressure data was not available and each unit is thin, hence only (oil down to) method can be recognized to locate the OWC. All wells have a different OWC and their depths tend to become deeper from west to east. OWC was defined for each unit at the depth where the calculated water saturation from logs interpretation process becomes downward to $100 \%$.

\section{9- Property Modelling}

Property modelling is used to characterize the spatial distribution and variation of reservoir physical parameters between wells [10]. These properties are the main indicator for reservoir quantitative evaluation [11]. The database of property modelling were the logging interpreted curves of each well. Stochastic modelling method was selected to build reservoir property models.

The classical geostatistical approach used to model the reservoir properties was the sequential simulation approach. Sequential Gaussian Simulation (SGS) was utilized to model petrophysical properties. Each cell of the 3D grid had values for petrophysical properties. The geostatistical calculation of rock properties involved variogram analysis and petrophysical properties estimation utilizing SGS as an interpolation method.

\section{9-1 Variogram Model}

Variogram-based geostatistical-modelling methods are employed in most reservoir characterization studies to accurately and efficiently describe reservoir heterogeneities. The 3D reservoir models are constrained by the variogram-based techniques on local data which represent the geologic knowledge and assist to create suitable flow behaviors through dynamic simulation. The variogram is used to identify and model the spatial structure of the petrophysical properties [12]. The experimental variogram is estimated by equation 1 below [13].

$$
2 \gamma(L)=\frac{\sum_{i=1}^{n(L)}[X(u i)-X(u i+L)]^{2}}{2 n(L)}
$$


The variogram is denoted by $2 \gamma(L)$, where $L$ represents a lag vector, $n(L)$ is pairs number, $\mathrm{x}_{\mathrm{ui}+\mathrm{L}}, \mathrm{x}_{\mathrm{ui}}$, are variables $\mathrm{x}$ at positions $\mathrm{L}$ and ui+L. At $\mathrm{L}=0$, the variogram starts from zero reaching a constant value (Sill: C) at a specific distance indicated as correlation length or range (a). The range refers to the data correlation over different orientations. Any data beyond the range are distinct of each other with no spatial structure. Hypothetically, the variogram has to be decreased to zero at $\mathrm{L}=0$, which is named nugget effect $\left(\mathrm{C}_{0}\right)$. Since experimental variogram is unable to provide these terms, it is not sufficient for variogram analysis. Hence, experimental variogram has to be fitted with suitable theoretical models. The most prevalent theoretical models used to fit the experimental variogram are the spherical, exponential and gaussian, that are contained in Petrel 2016 software. The spherical model is the most commonly applied to elucidate variogram. Spherical variogram equation can be represented by equations $2 \mathrm{a}$ and $2 \mathrm{~b}[13]$

$$
\begin{gathered}
M s a(L)=\gamma(L)=C 0\left[\frac{3}{2}\left(\frac{L}{a}\right)-\frac{1}{2}\left(\frac{L^{3}}{a^{3}}\right)\right] \\
\text { If } L \leqq \mathrm{a} \\
\text { and } M s a(L)=\mathrm{C}_{0}
\end{gathered}
$$

if $\mathrm{L} \geqq \mathrm{a}$, where $\mathrm{M}_{\mathrm{sa}}(\mathrm{L})=$ a spherical model with a range $\mathrm{a}$.

The spherical model is expressed by a sill value of $\mathrm{C}_{0}$ and domain a. Besides, it results in maximum slope are originally compared to other models (Figure-6) [6]. Hence, if a calculated variogram increased rapidly for a particular range, the spherical model represents the better choice attempting to model the variogram.

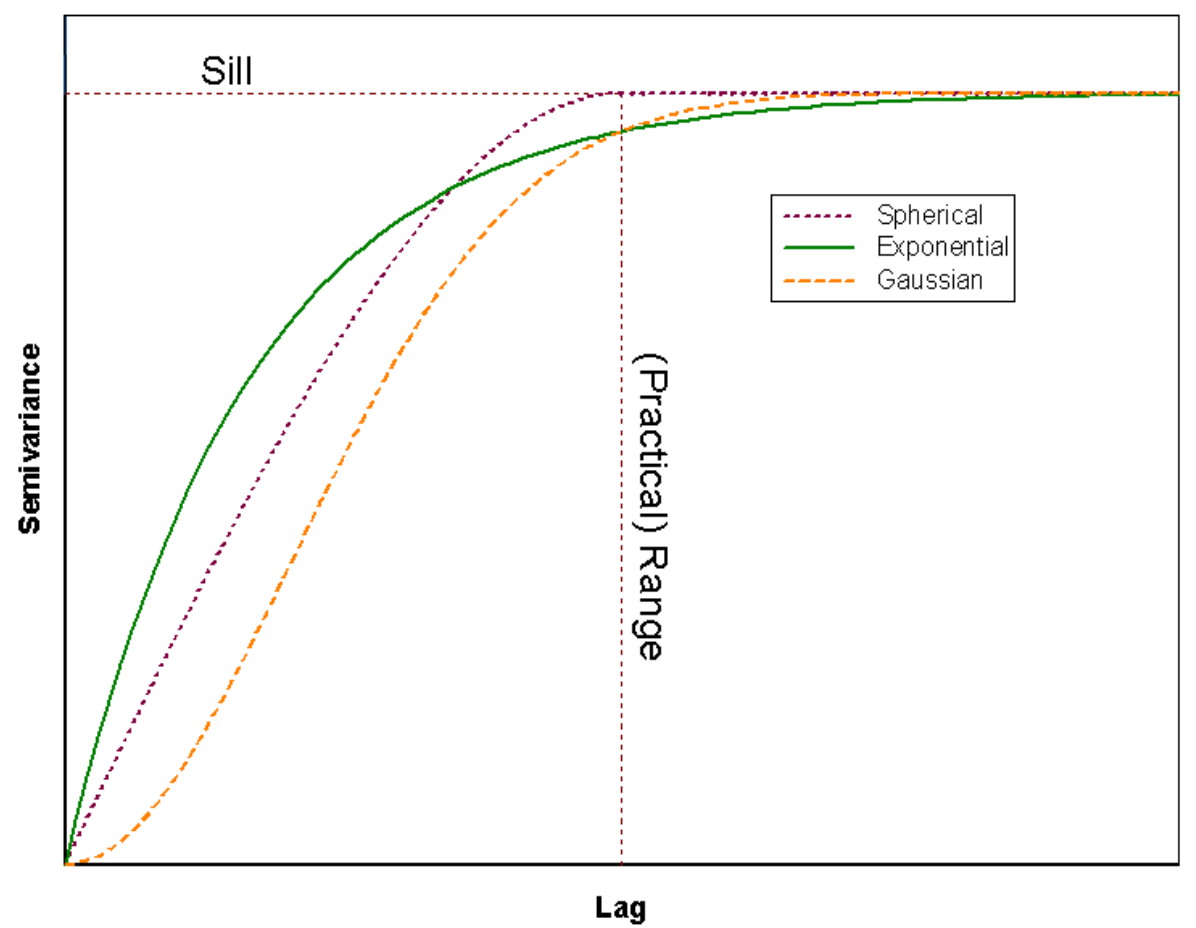

Figure 6-Covariance models with sill

The analysis of variogram was performed by applying two steps; first, identifying variogram's vertical, major, and minor directions. Second, spherical model processing to fit the experimental variogram to each trend.

The Azimuth angle in major direction was set to be $327^{\circ}$ and $237^{\circ}$ in minor direction. The parameters that are necessary to describe major and minor orientations are lag, lag distance (approaches to the distance among wells) and azimuth. Other parameters taken into consideration are search radius (i.e. further separation distance for sample pairs used in the search), bandwidth which is used to prevent the area of the search from changing very wide at large separation distance, and the tolerance angle that is the angle width calculated from the main axis of search cone [13]. Table-2 summarizes major and minor trends' parameters. The outcomes of the vertical trend parameters are 
varied for each unit. The resulted nugget values of a spherical model for porosity and water saturation for all Mishrif Formation units were equal to (0). The values of other parameters are listed in Table-3.

Table 2-Search Cone Parameters

\begin{tabular}{|cccc|}
\hline Major & 327 & 0 & 14 \\
\hline Minor & 237 & 0 & 14 \\
\hline Direction & Lag Distance. & Radius & Bandwidth \\
\hline Major & 1271.7 & 25434 & 12134.7 \\
\hline Minor & 1015.6 & 20312 & 11778.8 \\
\hline
\end{tabular}

Table 3-Parameters of variograms are delineated for porosity and saturation data from sphereical model.

\begin{tabular}{|c|c|c|c|c|c|}
\hline Unit & Sill & Major & Minor & $\begin{array}{c}\text { Vertical } \\
\text { direction }\end{array}$ & Property \\
\hline Mishrif Top-MA & 1.0073 & 5387.567 & 4708.327 & 5.052 & Porosity \\
\hline MA-Shale & 0.9982 & 6019.898 & 5229.026 & 35.628 & Porosity \\
\hline Shale-MB1 & 0.9168 & 6035.027 & 5334.421 & 7.869 & Porosity \\
\hline MB1-MB2 & 0.9958 & 3464.164 & 3536.798 & 28.386 & Porosity \\
\hline MB2-Rumaila & 0.9864 & 3867.363 & 5475.089 & 8.27 & Porosity \\
\hline Mishrif Top-MA & 0.9309 & 5257.639 & 5011.941 & 9.88 & Water saturation \\
\hline MA-Shale & 0.9936 & 5195.531 & 5905.759 & 32.409 & Water saturation \\
\hline Shale-MB1 & 0.9948 & 7112.716 & 5877.302 & 7.868 & Water saturation \\
\hline MB1-MB2 & 0.993 & 5011.838 & 3590.313 & 30.8 & Water saturation \\
\hline MB2-Rumaila & 0.9896 & 4126.576 & 5238.217 & 13.499 & Water saturation \\
\hline
\end{tabular}

\section{9-2 Porosity Modelling}

The key phase of this study was the distribution of the petrophysical properties. The distribution of porosity across the field was carried out utilizing geostatistic interpolation. The well logging interpreted and corrected porosity within Techlog 2015 software was taken as the control point after applying a cutoff to the porosity curve (porosity $\geq 5$ ) as resulting from the log interpreted porosity vs special core analysis of porosity relationship. Furthermore, well porosity distribution characteristics of each well, and each geological layer and variogram ranges (Tables- 2 and 3), were used as constraint conditions. SGS method was applied to build effective porosity model. Figure-7 shows a cross-section in the W-E direction of porosity distribution for Mishrif Formation which resulted from porosity modelling process. 


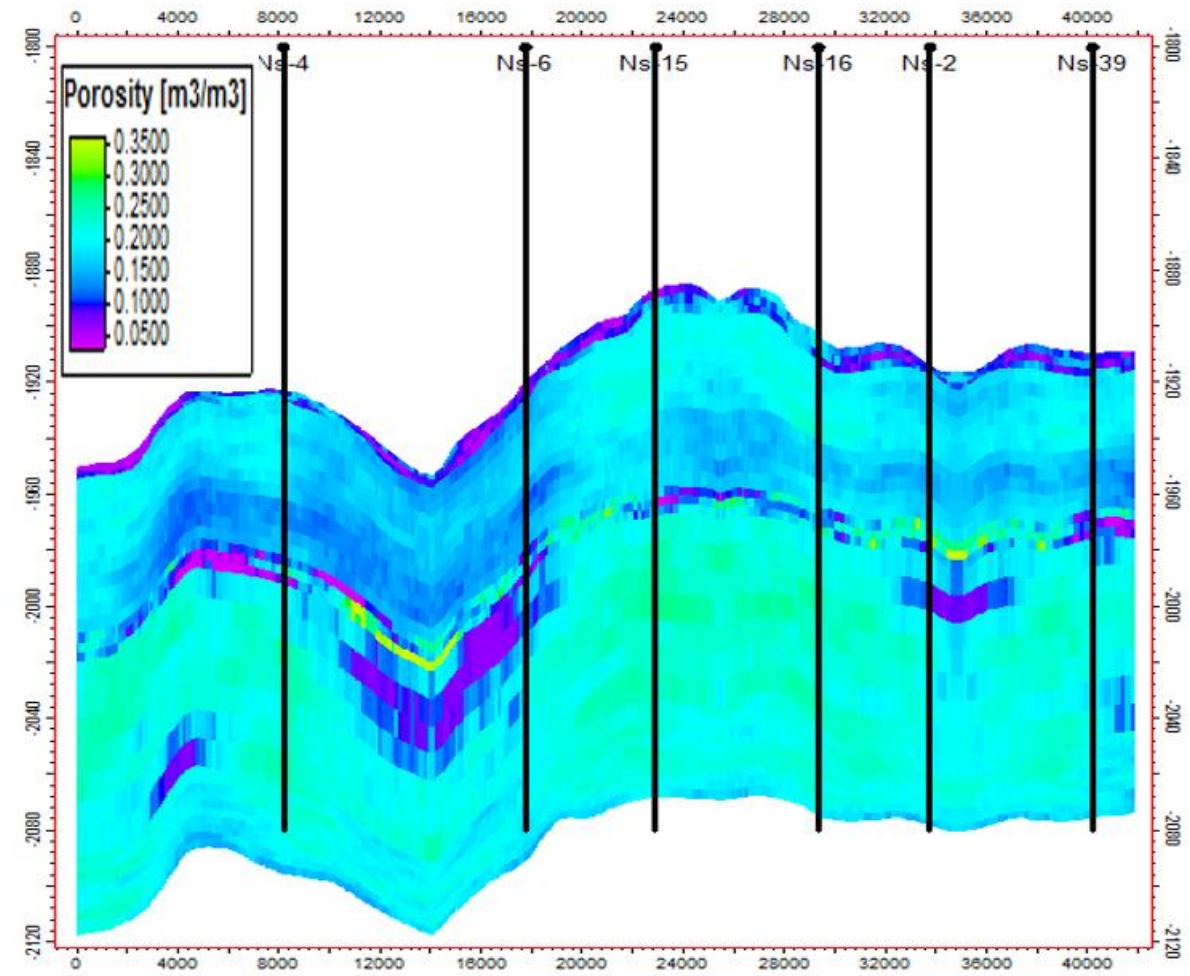

Figure 7-Cross-section in W-E direction of porosity distribution for Mishrif Formation in Nasiriyah oilfield

\section{9-3 Water Saturation Modelling}

Depending on the logging interpreted curves exported from Techlog software, a water saturation model was created for Mishrif reservoir units. The used geostatistical method was SGS and the variogram ranges were applied as in Tables-(2) and (3). A cross-section was built in W-E direction to illustrate the distribution of water saturation for Mishrif Formation, as shown in Figure-8.

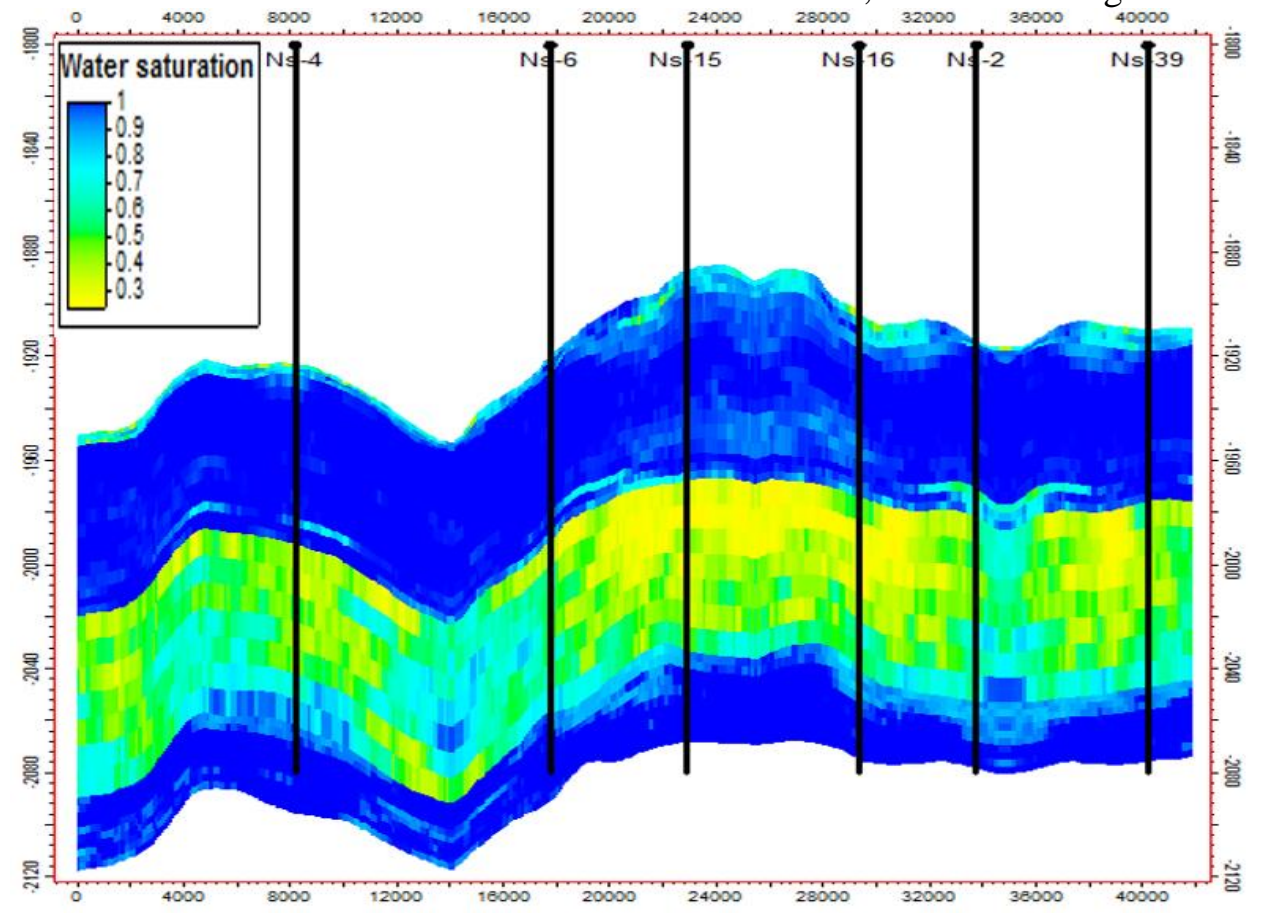

Figure 8-Cross-section in W-E direction of water saturation distribution for Mishrif Formation in Nasiriyah oilfield. 


\section{0- Initial Oil In-place Calculation (OOIP)}

The volumetric method was adopted for OOIP calculation. Oil-water contacts of different units were set by the analysis of well logs results. 3D parameter models were used for accurate OOIP estimation, involving structural model, effective porosity, water saturation and net to gross (NTG) model, that was calculated according to the cut-off values of porosity of $\geqq 5 \%$ and water saturation of $\leqq 60 \%$, and the bulk rock volume. For parameters relevant to fluid, including initial oil volume factor and solution gas-oil ratio, laboratory test data were assigned to the models. The resulted initial oil in place value for Mishrif Formation obtained by Petrel 2016 was about $7945^{*} 10^{6}$ stock tank barrel (STB).

\section{1- Results and Discussion}

Mishrif reservoir was divided into five units, each with specific reservoir properties, and the outcomes are presented as follow:

1- Mishrif Top: This unit is mainly consisting of compacted limestone of thickness ranges between 3$11.5 \mathrm{~m}$. The top of Mishrif was interpreted as a cap rock with an average porosity of $5 \%$. Some parts of this unit show an increase in porosity, reaching $11 \%$, because of the fine grains nature of Mishrif Formation rocks. The average water saturation for this unit was $76.9 \%$.

2- MA unit: This unit starts with the appearance of porous limestone which was recognized by the well $\log$ data. The thickness of this unit ranges between $49-62.5 \mathrm{~m}$ and the average porosity value was $17.55 \%$. It was interpreted as water-bearing unit according to the high average water saturation value of $97.8 \%$, as shown in Figure-8.

3- Shale Bed: This unit appears to act as a sealing barrier between the MA and MB1 units. Porosity mean value for this unit was $18.32 \%$ and the mean water saturation value was $88.2 \%$. The thickness of this unit is ranging between $5-18 \mathrm{~m}$ and it is impermeable, thus it was identified as a non-reservoir unit.

4- MB1 unit: It represents the main reservoir and the only productive unit in Mishrif Formation with thickness ranging between 63-70 m. The upper part of this unit shows poor reservoir properties in the eastern wells (Ns-1,2,3) which improve towards the west (Ns-4,5) with a high average porosity value of $20.88 \%$ and a low water saturation of $16.9 \%$, compared with the other units. This unit is productive in all the wells under study.

5- MB2 unit: The thickness of this unit is ranging between 27-37 m, with good reservoir properties. However, it was almost completely water-bearing where the mean values for porosity and water saturation were $20.81 \%$ and $96.25 \%$, respectively.

6- According to the cross-sections that were built in the W-E direction for porosity and water saturation, the optimum locations characterized by good reservoir properties were found in the wells Ns-5, Ns-15, Ns-16, Ns-38 and Ns-40 which are located near the crest of Mishrif Formation structure.

\section{2- Conclusions}

The study was performed to evaluate the petrophysical properties and build a $3 \mathrm{D}$ geological model, thus estimating the reserve of Mishrif Formation in Nasiriyah oilfield. The following conclusions were made from this study:

The constructed geological model can objectively reflect the distribution of reservoir petrophysical properties in 3D space under the condition of the currently available data.

Petrophysical properties models for Mishrif Formation in Nasiriyah oilfield were designed utilizing the statistical method of sequential Gaussian Simulation algorithm rule after the well logs were scaled up. The results showed that the main reservoir unit of Mishrif Formation is MB1 characterized by good reservoir properties. The top of Mishrif Formation represents cap rock and the shale bed which act as a sealing barrier extending generally in the middle of Mishrif Formation all around Nasiriyah oilfield, while MA is a water-bearing unit. MB2 has good reservoir properties with high average water saturation.

The variogram is essential for any reservoir modelling study and was applied here through geostatistical reservoir modelling. The variogram represents a measurement for the property spatial variation, which in turn reflected the true heterogeneity of Mishrif Formation. Compared to other statistic methods including kriging, kriging interpolation and Gaussian random function simulation, the best method for petrophysical properties distribution, including porosity and water saturation, was the sequential Gaussian Simulation. 
The accuracy of petrophysical properties modelling has a large influence on constructing a good geological model, that represents the reservoir model structure, and effects the value of pore volume, thus changing the value of oil in-place where the estimated value of initial oil in-place for Mishrif Formation / Nasiriyah oilfield calculated by Petrel 2016 was about $7945^{*} 10^{6}$ stock tank barrel (STB).

\section{3- Acknowledgments}

The authors would like to show their gratitude to Thi-Qar Oil Company for providing the required data to achieve this study

\section{References:}

1. S.O.C., South Oil Company, S.O.C. 1990. "Geological study of Mishrif formation in Nasiriyah oilfield".

2. Hlelai, M.A. and S. Z. Khorshid, S.Z. 2015. "3-D lithofacies Model of Mishrif Formation in Nasiriyah oil field Southwestern Iraq," Hlelai Khorshid Iraqi J. Sci., 56(4C): 3452-3462.

3. Kadhim, F.S., Samsuri, A. and Alwan, H. 2015. "Determination of Lithology, Porosity and Water Saturation for Mishrif Carbonate Formation," Int. J. Environ. Chem. Ecol. Geol. Geophys. Eng., 9(8): 987-993.

4. Al-Baldawi, B.A. 2015. "Building A 3D Geological model Using Petrel Software for Asmari Reservoir, South Eastern Iraq," Iraqi J. Sci., 56(2C): 1750-1762.

5. Abdullah, M.D., Nasser, M.E. and Al-Yasseri, A.A. 2019. "Building a $3 D$ petrophysical model for Mishrif formation in Nasiriyah oil field, southern Iraq," Iraqi J. Sci., 60(1): 115-126.

6. Perez, K. 2002. "Applied_Geostatistics_for_Reservoir_Char.pdf.".

7. ali Faeq, S. 2013. "Permeability Prediction and 3D Petrophysical Model for Khasib Formation / Ahdeb Field,".

8. Schlumberger, 2008. Petrel introduction course, Schlumberger, 50-334p, 2008.

9. Lie, K.A. 2019. "Upscaling Petrophysical Properties," An Introd. to Reserv. Simul. Using MATLAB/GNU Octave, pp. 558-596.

10. Kamali, M.R., Omidvar, A. and Kazemzadeh, E. 2013. "3D Geostatistical Modeling and Uncertainty Analysis in a Carbonate Reservoir, SW Iran," J. Geol. Res., 2013, pp. 1-7, 2013.

11. Al-Musawi, F.A., Idan, R.M. and Salih, A.L.M. 2019. "Reservoir Properties and Facies Distribution of Mishrif Formation in Ratawi Oilfield, Southern Iraq," in The Structural Geology Contribution to the Africa-Eurasia Geology: Basement and Reservoir Structure, Ore Mineralisation and Tectonic Modelling, Springer, pp. 121-126.

12. Adeoti, L.,Onyekachi, N., Olatinsu, O., Fatoba, J. and Bello, M. 2014. "Static Reservoir Modeling Using Well Log and 3-D Seismic Data in a KN Field, Offshore Niger Delta, Nigeria," Int. J. Geosci., 05(01): 93-106.

13. Nixon, J.V. 2001. "Introduction to Geostatic and Variogram Analysis," Relig. Arts, 5(1-2): 2-12. 